\title{
RECORDS OF OLIGOCHAETES IN FRESHWATER SPONGES, ON BRYOZOANS, AND ON COLONIAL HYDROZOANS FROM BRAZIL
}

\author{
CORBI, J. J., ${ }^{1}$ ROQUE, F. O., ${ }^{1}$ TRIVINHO-STRIXINO, S. ${ }^{1}$ and ALVES, R. G. ${ }^{2}$ \\ ${ }^{1}$ Laboratório de Entomologia Aquática, Departamento de Hidrobiologia, Universidade Federal de São Carlos, \\ C.P. 676, São Carlos, SP, Brazil \\ ${ }^{2}$ Centro Universitário de Araraquara, UNIARA, Araraquara, SP, Brazil \\ Correspondence to: Juliano J. Corbi, Laboratório de Entomologia Aquática, Departamento de Hidrobiologia, \\ Universidade Federal de São Carlos, C.P. 676, São Carlos, SP, Brazil, e-mail: pjcorbi@iris.ufscar.br \\ Received April 24, 2003 - Accepted July 7, 2003 - Distributed February 28, 2005
}

Species of oligochaetes inhabiting other freshwater animals have been cited by Brinkhurst \& Jamieson, 1980; Righi, 1984; Brinkhurst \& Marchese, 1991. However, there are few published studies about the Brazilian species (Righi, 1984). Here, we report oligochaeta species inhabiting freshwater sponges, as well as on bryozoans and hydrozoans from some Brazilian aquatic ecosystems.

The material was collected by divers mainly on large rocks (depth $>15 \mathrm{~m}$ ) in the Paraná river channel $\left(20^{\circ} 45^{\prime} \mathrm{S}\right.$ and $\left.51^{\circ} 40^{\prime} \mathrm{W}\right)$ and manually in the Jacaré-Guaçu river basin (21 ${ }^{\circ} 53^{\prime} \mathrm{S}$ and $47^{\circ} 52^{\prime} \mathrm{W}$ ) (Table 1). The aquatic worms were sorted under stereoscopic microscope, processed, and identified following Righi (1984), and Brinkhurst \& Marchese (1991). The identification of bryozoans and hydrozoans followed Wood (1991) and Slobodkin \& Bossert (1991) respectively, and the sponges were identified by Dra. Cecília Ribeiro-Volkmer. The organisms have been deposited in the collection of the Aquatic Entomology Laboratory of the Federal University of São Carlos, SP, Brazil, except for the freshwater sponges that have been deposited in the Museum of Natural Sciences of the Zoobotanical Foundation, Rio Grande do Sul, RS, Brazil.
We recorded 4 species of aquatic oligochaetes of the Naididae family (Table 1). Other authors have also found Naididae inhabiting aquatic animals: e.g., Kahl \& Konopacka (1981) found high abundance of Naididae, particularly the genus Nais, living in Spongilla lacustris; Anderson \& Holm (1987) and Fernandez et al. (1991) studied commensal and predatory relationships between Chaetogaster and mollusks; and Marcus (1941) referred to Naididae on Brazilian bryozoans.

Oligochaetes probably are neither particularly characteristic of nor strongly connected with their hosts, as has been pointed out for sponges by Kahl \& Konopacka (1981). However, more information is required on this matter, especially considering that commensalism in freshwater may involve evolutionary advantages, such as better feeding opportunities, increased mobility, protection from disturbances, and reduced risk of predation (Tokeshi, 1993).

Acknowledgements - We would like to thank Antonio Pacheco for aid in field work in the Paraná river channel and to Claudia Gerth for the English revision. We also like thank Dra. Cecília Ribeiro-Volkmer for identifying the sponges. The State of São Paulo Research Foundation (FAPESP), within the BIOTA/FAPESP - The Biodiversity Virtual Institute Program (www.biotasp.org.br), supported this work. 
TABLE 1

Occurrence of oligochaetes in freshwater sponges, on bryozoans, and on hydrozoans from different Brazilian aquatic systems.

\begin{tabular}{|c|c|c|}
\hline Oligochaeta & Host animal & Site \\
\hline Chaetogaster langi & Oncosclera navicela & Paraná river, \\
Bretscher, 1896 & Carter, 1881 & Três Lagoas, \\
& Corvospongilla seckti & Mato Grosso do Sul \\
& Bonetto \& Ezcurra de Drago, 1966 & \\
& (Spongiae) & \\
& Urnatella gracilis & \\
& Leydi & \\
& (Entoprocta) & \\
& Cordylophora caspia & \\
& Pallas, 1771 \\
(Hydrozoa) & \\
\hline Pristina proboscidea & Radiospongilla amazonensis Volkmer & Espraiado stream \\
Beddard, 1896 & Ribeiro \& Maciel, 1983 & (Spongiae) \\
& (Jacaré-Guaçu river basin) \\
\hline Nais communis & Radiospongilla amazonensis Volkmer & Carlos, São Paulo \\
\hline Piguet, 1906 & Ribeiro \& Maciel, 1983 & Espraiado stream, \\
& (Spongiae) & (Jacaré-Guaçu river basin) \\
& São Carlos, São Paulo \\
\hline Nais simplex & Oncosclera navicela & Paraná river, \\
Piguet, 1906 & Carter, 1881 & Três Lagoas, \\
& (Spongiae) & Mato Grosso do Sul \\
\hline
\end{tabular}

\section{REFERENCES}

ANDERSON, R. V. \& HOLM, D. J., 1987, Chaetogaster-limnaei (Oligochaeta, Naididae) infesting unionid mollusks (Pelecypoda, Unionidae) and Corbicula-fluminea (Pelecypoda, Corbiculidae) in pool-19, Mississippi river. J. Freshwater Ecol., 4(1): 61-64.

BRINKHURST, R. O. \& MARCHESE, M. R., 1991, Guia para la identificación de oligoquetos acuáticos continentales de sur y centroamérica. Associación Ciencias Naturales del Litoral. J. Maciá, San Tome (3016), Argentina, 207p.

BRINKHURST, R. O. \& JAMIESON, B. G. M., 1980, Aquatic oligochaeta of the world. University of Toronto Press, 860p.

FERNANDEZ, J., GOATER, T. M. \& ESCH, G. W., 1991, Population-dynamics of Chaetogaster-limnaei-limnaei (Oligochaeta) as affected by a trematode parasite in Helisoma-anceps (Gastropoda). Am. Midl. Nat., 125(2): 195205.
KAHL, K. \& KONOPACKA, A., 1981, Oligochaeta inhabiting the colonies of the sponge Spongilla lacustris (L.) in the river Gac. Acta Hydrobiol., 23(3): 243-249.

MARCUS, E., 1941, Sobre Bryozoa do Brasil. Bolm Fac. Fil. Ci. Letras. Univ. São Paulo, Zoologia, 5: 3-208.

RIGHI, G., 1984, Manual de identificação de invertebrados Límnicos do Brasil. CNPq, Brasília, 48p.

SLOBODKING, L. B. \& BOSSERT, P. E., 1991, The freshwater Cnidaria - or coelenterates. In: J. H. Thorp \& A. P. Cowich. Ecology and classification of North American Freshwater invertebrates. Academic Press, Inc., 911p.

TOKESHI, M., 1993, On evolution of commensalism in the Chironomidae. Freshwater Biol., 29: 481-489.

WOOD, T. S., 1991, Bryozoans. In: J. H. Thorp \& A. P. Cowich. Ecology and classification of North American Freshwater invertebrates. Academic Press, Inc., 911p. 